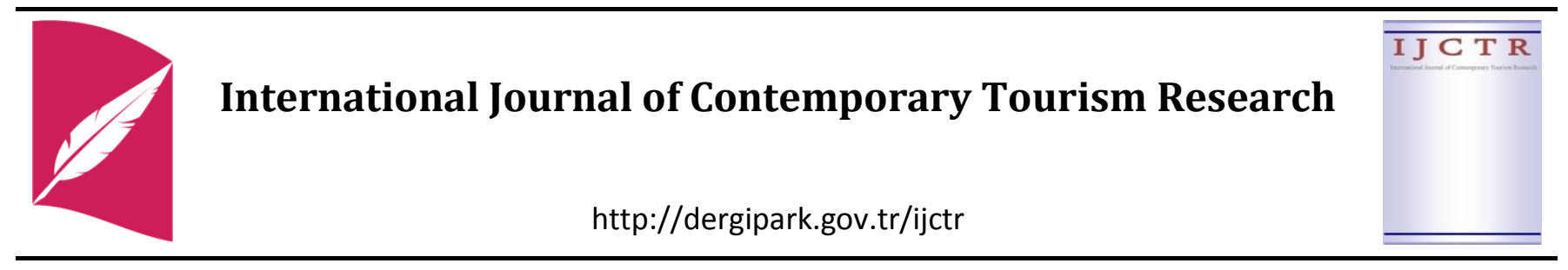

\title{
A CRITICISM OF CONTEMPORARY MASS TOURISM BY HISTORICAL ANALOGIC APPROACH
}

Research Article

Onur AKBULUT*

\begin{abstract}
This article underlines two historical analogic approaches as a criticism of the contemporary mass tourism. It is argued that western hegemony developed countries may originate contemporary mass tourism. According to historian and classicist Kagan (2007) two complementary main features of western civilization are Hellenism and Christianity. This article takes these complementary features into consideration with Leiper's (1981) Tourism System's two main components demand and supply. These four concepts were discussed using historical analogies. Demand vs (versus) Christianity (heaven portrayal) were chosen as the first analogy. Supply vs Hellenism (polis and subjects [helots] specific to Sparta city state) was proposed as the second analogy. These two analogies may help to gain a better understanding of mass tourism by means of a critic approach with regard to its proposed historical roots.
\end{abstract}

Keywords: Mass tourism, Historical analogy, Tourism system, Christianity, Hellenism.

Jel Codes: N93, L 83

* Assist. Prof., Muğla S1tkı Koçman University, Fethiye Faculty of Business, onurakbulut@mu.edu.tr, orcid.org/0000-0002-1392$243 \mathrm{X}$

Akbulut, O. (2018). A Criticism of Contemporary Mass Tourism by Historical Analogic Approach, International Journal of Contemporary Tourism Research, Vol 2: No: 2, p.52-59, doi: 10.30625/ijctr.470022

Submission Date: 12.10.2018

Acceptance Date: 19.10.2018 


\section{INTRODUCTION}

After 1950s, tourism has witnessed sustained accretion and product diversification, being world's regularly growing and high volume economic sector. International tourism and its patterns do not ingenerate coincidentally. Economic growth, cultural factors and access to transport are the consequences of it (Hall, 2008, p. 1). Considering the patterns of tourism and the areas that have the potential of development in terms of international tourism, it can be remarkably seen that most of the outbound tourists are from the developed countries and the new middle class in many developing countries. (Page, 2007, p.20). Likewise early example of first mass tourism activity occurred in England among the working class of new industrial age (Urry and Larsen, 2011, p. 2).

In 2017 there are 39 developed countries in world. United States, Euro zone (Germany, France, Italy and Spain), Japan, United Kingdom and Canada constitute the top five developed countries respectively. Additionally there are 153 developing countries in 2017 list (IMF, 2017). Numerically, developing countries are 3, 92 times more than developed countries.

Browsing worldwide tourism statistics in 2017, one can see that developed countries receive 685 million international tourist arrivals while developing countries receive 550 million international tourist arrivals. In terms of international tourism receipts, developed countries gain 787 billion dollars while developing countries gain 433 billion dollars (UNWTO, 2017).

Average tourism expenditure per tourist in developed countries was 870,39 dollars while it is 1270, 20 dollars for developing countries. Nevertheless 787 billion dollars shared by 39 countries while 433 billion dollars shared by 153 countries. These macro-economic statistics may appear optimistic for developing countries. However, it is suspicious that the fact is as it seems. When taking tourism into account by visitor and host perspective, a clear inequality can be seen. Tourist possesses the disposable income to enjoy the forms of tourism, whereas the host is to work in tourism or tourism-generated employment in exchange for lower and seasonal salaries. This condition is getting worse by the continuous development of globalization (Page, 2007, p.20).
According to an influential philosopher George Santayana (1905, p. 1) "those who cannot remember the past are damned to repeat it". This study is designed to be based on this famous quote. Nevertheless, similar to other authors, it is not wrong to be concerned about the perception of historical critics. As Peter Bol from Harvard University says (as cited in bbc.com) "Ideologically speaking, the Qin early Chinese Emperor, who was buried with 6000 life size terra cota soldiers, make the argument, 'We don't want to hear people criticize the present by referring to the past". Regardless, the importance of history told in this famous quote is the starting point of this article. Therefore, the theme of this article is an attempt to handle considers contemporary mass tourism movement differentiation between developed and developing countries of the world by through historical analogies. A critical approach has been put forward in terms of historical analogies in this article.

Why the contemporary tourism's biggest block mass tourism perceived as travelling to accommodation mostly located in attractions where sun, sea and sand is the main fascination? Are western civilization and its features having an impact on its perception amongst societies? What about the case of the host communities? Is it possible to clarify westerner hegemony tourism movement with the analogies of two main features of Western society as Hellenism and Christianity? These are the questions which this article tries to answer.

According to historian and classicist Kagan (2007) two complementary main features of western civilization are Hellenism and Christianity. The former initially was realized in Ancient Greece as a breaking point. The first one is Hellenism. Citystates named as "poleis" used to be founded as the republics. There existed relatively less difference among the urban population in terms of wealth. There was no king or ruler having the resources sufficient for affording soldiers of fortune. Consequently, urban citizens were to fight themselves to defend and they decided when to make war. Citizens demanded to play their role in the considerable decisions as the independent defenders of common interests and security. Thus, first steps of political life came into being. Herewith, one should not omit that the word of 
"politics" came from the root of "polis" in ancient Greek. Before this era, there used to be no word to identify, because there was no need to define such a situation. This political life was shared by a relatively large population and it was of great importance for ancient Greek citizens to participate in political life. Such type of states did not need bureaucracy, since they did not possess large amounts of state and/or royal assets. The reason behind this was the unavailability of economy which can feed and/or support a bureaucratic class in the society. There existed no distinct class of priests. Moreover, there was no interest in the life after death which was universally important in any other civilizations (Kagan, 2007, p. 2).Consequently Hellenic civilization's creative ideals and commitment to human selfimprovement, contestation, and linear thought transformed everything it touched and laid the foundations Western civilization (Hause and Maltby, 2004, p. 23).

Second milestone of the western history is the Jewish-Christian tradition, which is absolutely different from aforementioned ancient Greek one. The principal roots of Christianity are in Judaism. This belief is distinctive from the human beings; it has considerable moral demands from the believers and venerates a puissant god who can judge even the emperors and kings. Christianity started to be spread as an oppressed religion and positioned as the enemy of Ancient Rome, Roman Empire and generally the secular state. Eventually this belief captured Rome. Christianity has always been independent from the state and positioned opposite of it. With the claims that challenge to secular authority, it has never completely lost its initial rebel features.

This is also intrinsic to west, like the originality of Ancient Greek experiences. Such type of religious organization has not existed in any human society. In this way, the unification of a universal religion and the Roman Empire as a huge political hegemon; might have put an end to the expectations of freedom and possibilities just like experienced in the other civilizations. Nonetheless, as the Christianity took over and inherited the heritage of rational and philosophical discussions, this fact led to the schismatically struggles related to the questions about the nature of the god and the other theological questions. This situation was suitable to the Greek tradition of philosophical discussion. Here, Kagan's (2007) suggestion stresses that even though Jewish-Christian tradition has been distinctive from Greeks and sometimes this belief has positioned completely opposite of them, this aspect of Greek culture has existed in the nature of Christianity and it is of great importance. That is to say, Christianity has somewhat ancient Greek sources in its very nature.

In order to answer the questions above, this research proposes two historical analogies in consideration of tourism system model. In Leiper's (1981, p. 75) much cited tourism system model, tourism is separated into parts such as tourism generating and tourist destination regions. Tourism system model can be seen in Figure 1. First analogy centers upon demand component of the tourism system model. Second analogy set sight on the supply component of the tourism system model.

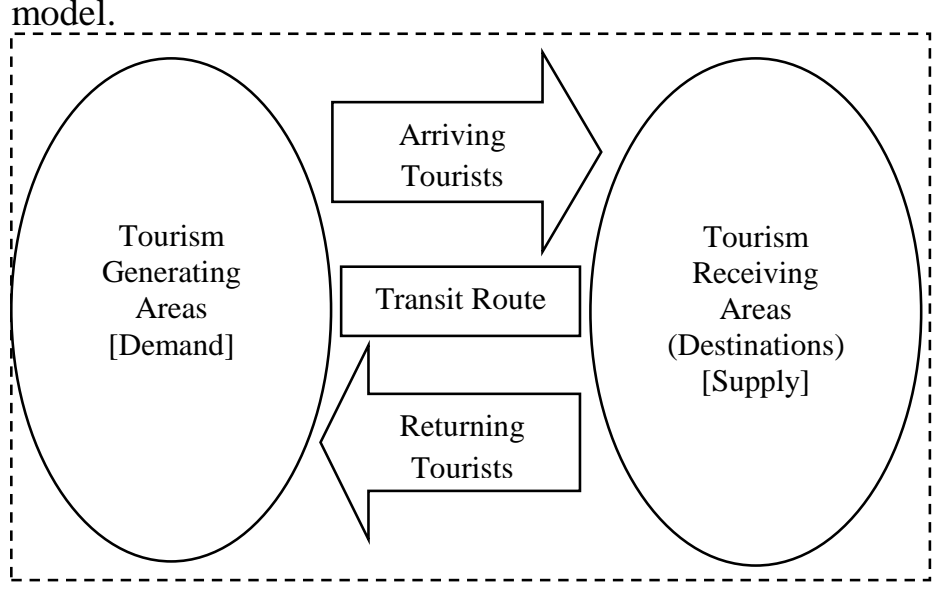

Figure 1: Tourism system model

Source: Leiper (1981, p. 75)

\section{DEMAND vs. CHRISTIANITY}

According to UN (2016) estimated world population is 7466964 (in thousands) in 2016. Figure 2 demonstrates the distribution of world population by latitude and longitude in 2015 . The population distribution is not an equally collated distribution. Disequilibrium between the advanced and developing countries is the main starting point of the first historical analogic approach. 


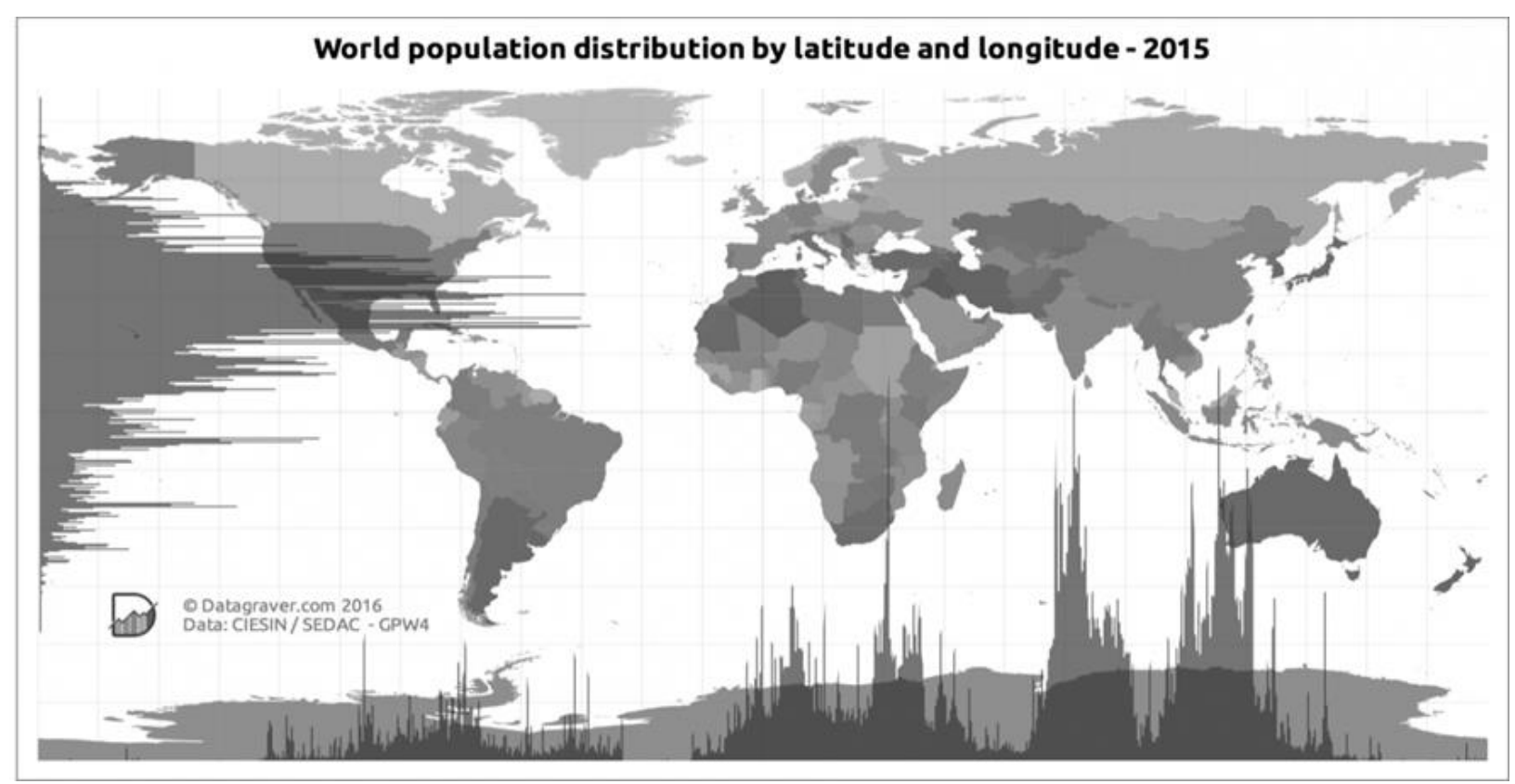

Figure 2: World population distribution by latitude and longitude-2015

Source: http://www.datagraver.com/case/world-population-distribution-by-latitude-and-longitude-2015

A table of developed countries with regard to their east-west location and religion can be seen in Table 1.

Table 1: East-west and religious distinctions of developed countries

\begin{tabular}{|c|c|c|c|c|}
\hline No & \multicolumn{2}{|l|}{ Country } & $\begin{array}{l}\text { East or } \\
\text { West }\end{array}$ & $\begin{array}{l}\text { Major } \\
\text { Religions }\end{array}$ \\
\hline 1 & \multicolumn{2}{|l|}{ United States } & West & Christianity \\
\hline 2 & Germany & \multirow{17}{*}{ 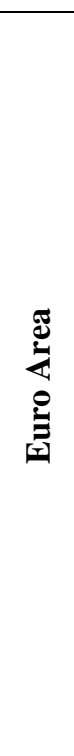 } & West & Christianity \\
\hline 3 & France & & West & Christianity \\
\hline 4 & Italy & & West & Christianity \\
\hline 5 & Spain & & West & Christianity \\
\hline 6 & Netherlands & & West & Christianity \\
\hline 7 & Belgium & & West & Christianity \\
\hline 8 & Austria & & West & Christianity \\
\hline 9 & Greece & & West & Christianity \\
\hline 10 & Portugal & & West & Christianity \\
\hline 11 & Finland & & West & Christianity \\
\hline 12 & Ireland & & West & Christianity \\
\hline 13 & $\begin{array}{l}\text { Slovak } \\
\text { Republic }\end{array}$ & & West & Christianity \\
\hline 14 & Slovenia & & West & Christianity \\
\hline 15 & Luxembourg & & West & Christianity \\
\hline 16 & Estonia & & West & Christianity \\
\hline 17 & South Cyprus & & West & Christianity \\
\hline 18 & Malta & & West & Christianity \\
\hline 19 & \multicolumn{2}{|c|}{ Japan } & East & Shintoism \\
\hline 20 & \multicolumn{2}{|c|}{ United Kingdom } & West & Christianity \\
\hline 21 & \multicolumn{2}{|c|}{ Canada } & West & Christianity \\
\hline
\end{tabular}

\begin{tabular}{|l|l|l|l|}
\hline 22 & Korea & East & $\begin{array}{l}\text { Christianity- } \\
\text { Buddhism }\end{array}$ \\
\hline 23 & Australia & West & Christianity \\
\hline 24 & Taiwan & East & $\begin{array}{l}\text { Buddhism- } \\
\text { Taoism }\end{array}$ \\
\hline 25 & Sweden & West & Christianity \\
\hline 26 & Switzerland & West & Christianity \\
\hline 27 & Hong Kong & East & $\begin{array}{l}\text { Buddhism- } \\
\text { Taoism }\end{array}$ \\
\hline 28 & Singapore & East & Buddhism \\
\hline 29 & Czech Republic & West & Christianity \\
\hline 30 & Norway & West & Christianity \\
\hline 31 & Israel & East & Judaism \\
\hline 32 & Denmark & West & Christianity \\
\hline 33 & New Zealand & West & Christianity \\
\hline 34 & Iceland & West & Christianity \\
\hline
\end{tabular}

Source: Adapted by authors from "United Nations Statistics Division Population by Religion, Sex and Urban/Rural Residence 2014 and International Monetary Fund World Economic Outlook" (2017). Christians are the largest religious group with $31 \%$ of the in world. Christians followed by $24,1 \%$ Muslims, 16\% Unaffiliated, 15,1\% Hindus, 6,9\% Buddhists and 5,7\% Folk religions (Pew Research Center, 2017).

According to Table 1, 28 out of the 34 developed countries are western countries while only 6 of them are eastern countries. In view of major 
religions, conformably 28 out of 34 developed countries have Christianity as their major religions.

When outbound international tourism statistics is taken into consideration, latest up to date data shows: "The large majority of international travel takes place within travelers' own regions (intraregional tourism), with about four out of five arrivals worldwide originating in the same region. Traditionally the advanced economies of Europe, the Americas and Asia and the Pacific have been the world's major source markets for international tourism. Even so, emerging economies in Asia, Central and Eastern Europe, the Middle East, Africa and Latin America have shown fast growth over recent years, driven by rising levels of disposable income. Europe currently still remains the world's largest source region for outbound tourism, generating almost half of the world's international arrivals (48\%), followed by Asia and the Pacific (26\%), the Americas (17\%), the Middle East (3\%) and Africa (3\%)"(UNWTO, 2017).

Table 2: Top spenders in international tourism

\begin{tabular}{|c|c|c|c|c|c|c|c|c|c|c|c|c|}
\hline \multirow{3}{*}{\multicolumn{2}{|c|}{ Rank }} & \multirow{2}{*}{\multicolumn{2}{|c|}{$\begin{array}{l}\text { International tourism } \\
\text { expenditure (uSs bullon) }\end{array}$}} & \multirow{2}{*}{\multicolumn{2}{|c|}{$\begin{array}{l}\text { Local currencles } \\
\text { change (\%) }\end{array}$}} & \multirow{3}{*}{$\begin{array}{c}\text { Market } \\
\text { share }(\mathrm{K}) \\
2016^{\circ}\end{array}$} & \multirow{3}{*}{$\begin{array}{c}\begin{array}{c}\text { Population } \\
\text { (million) }\end{array} \\
2016\end{array}$} & \multirow{3}{*}{$\begin{array}{c}\text { Expendture per } \\
\text { caplta (USS) } \\
2016^{\circ}\end{array}$} & \multicolumn{4}{|c|}{ International departures (millisa) } \\
\hline & & & & & & & & & \multicolumn{2}{|c|}{ Total including same-day } & \multicolumn{2}{|c|}{ of which overnight } \\
\hline & & 2015 & $2016^{*}$ & $15 / 14$ & $16 \% / 15$ & & & & 2015 & $2016^{*}$ & 2015 & $2016^{*}$ \\
\hline 1 & Crina & 2498 & 261.1 & 11.4 & 11.7 & 21.4 & 1,383 & 189 & 127.9 & 135.1 & - & - \\
\hline 2 & United States & 114.7 & 123.6 & 8.6 & 7.8 & 10.1 & 323 & 392 & 130.4 & .. & 74.0 & - \\
\hline 3 & Germany & 77.5 & 79.8 & -0.6 & 3.2 & 6.5 & 83 & 964 & .. & - & 83.7 & - \\
\hline 4 & Unlted Kngdom & 63.3 & 63.6 & 88 & 13.8 & 5.2 & 66 & 970 & 65.7 & $70 B$ & 64.2 & 69.4 \\
\hline 5 & France & 39.3 & 40.5 & -3.5 & 3.3 & 3.3 & 65 & 627 & 30.6 & - & 26.6 & - \\
\hline 6 & Canada & 30.1 & 29.1 & 1.3 & 0.0 & 2.4 & 36 & 802 & 56.0 & 53.0 & 32.3 & 31.3 \\
\hline 7 & Korea (ROK) & 25.3 & 26.6 & 9.0 & 5.4 & 2.2 & 51 & 520 & 19.3 & 22.4 & .. & - \\
\hline 8 & taty & 24.4 & 25.0 & 1.4 & 2.4 & 2.0 & 61 & 411 & 61.2 & 62.6 & 27.9 & 28.7 \\
\hline 9 & Australa & 23.8 & 24.9 & 6.1 & 6.0 & 2.0 & 24 & 1.026 & 9.5 & 9.9 & 9.5 & 9.9 \\
\hline 10 & Hong Kong (Crina) & 23.1 & 24.2 & 4.7 & 5.1 & 2.0 & 7 & 3,284 & 89.1 & 918 & -. & - \\
\hline
\end{tabular}

Source: UNWTO Tourism Highlights (2017, p. 13).

Latest statistics for international tourism spenders presented in Table 2 are a good example of Western and developed hegemon tourism or mass tourism system in world. For this reason, it was decided to make the analogy of demand component of the tourism system model according to first characteristics of western culture as Christianity. It is not would not be wrong to propose the following analogic approach about the demand component of the tourism system model in terms of mass tourism according to the abovementioned facts. As the demand part, tourist may perceive and orientate the understanding of Mass Tourism in the roots of afterlife beliefs of Christianity.

Target and source notions of demand and Christianity presented in Table 3 . The origins of mass tourism understanding tried to explain with the analogy presented on Table 3.
Table 3: Target and source notions of demand and christianity

\begin{tabular}{|l|l|}
\hline Target Notion & Source Notion (Analog) \\
\hline $\begin{array}{l}\text { Advanced Countries } \\
\text { (demand: tourist) }\end{array}$ & Heavenly \\
\hline Disposable Income & Goodness \\
\hline $\begin{array}{l}\text { Tourism: Leisure, Travel, } \\
\text { Accommodation, Food } \\
\text { and Beverage }\end{array}$ & $\begin{array}{l}\text { Heaven: Leisure (no need } \\
\text { to work.), Travel (descend } \\
\text { Accommodation (eternal } \\
\text { comfort, pleasure and } \\
\text { fun), Food and Beverage } \\
\text { (abundant, delicious and } \\
\text { eternal toughness) }\end{array}$ \\
\hline $\begin{array}{l}\text { Periodical (one need to } \\
\text { return from the created } \\
\text { heavenly atmosphere at } \\
\text { the end of the holiday) }\end{array}$ & Eternal \\
\hline
\end{tabular}

According to Cambridge Dictionary Online (2018) heaven is defined as "in some religions, the place, sometimes imagined to be in the sky, where God or the gods live and where good people are believed 
to go after they die, so that they can enjoy perfect happiness".

Aforementioned two traditions of western civilization possess some views about the society. In Holy Bible it is written that god put the human in Garden of Eden after having decided to create it. At first, only Adam was there. Later on, god thought that Adam needed a friend somewhat and created Eve. Both were living in heaven, one man and one woman, everything was perfect in the initial phase. Afterwards, they sinned against the god and they ate the fruit of the knowledge tree. If fruit had been eaten, then humans would have become divine, and this is not acceptable. In the end, they were expelled from the heaven as a punishment (Kagan, 2007, p. 4).

Upon death, Christians believe that they come before God and are judged. According to Smith (1991, p. 355), "Following death, human life is fully translated into the supernatural domain". Fundamentalists and conservatives interpret the Holy Bible literally and believe that there is a specific heaven and hell and that only Christians are admitted to heaven. All others are condemned to hell.

In the light of this information, most of the tourist travels to a heavenly destination outside of their usual environment during the mass tourism activities which one may dream and desire during one's normal life. The understanding of heaven in monotheistic religions is very analog to the mass tourism and its tourist. A good believer promised to be accepted heaven where one doesn't need to work, live freely in a pleasant, joyful eternal life. Analogously tourist for a period of time leaves one's usual environment and arrives to destination stay in luxury accommodation where food and beverage abundant and no need to work.

\section{SUPPLY vs. HELLENISM}

It is surprising that Ancient Greek Culture has still been attracting the citizens of $21^{\text {st }}$ century. Generally, this fact is based on the identification of Greeks in the most significant starting point in the western civilization which formed not only the western part but also the world as a whole.

The second characteristic of western civilization maybe considered as the believing of Hellenic origin shared by the western societies. Present day it may not wrong to say that world is under the Western hegemony with the reality of advanced countries mostly comprise of Western and Christian countries. But Western civilization built upon the progress of a ways greater historic societies. The peoples of the historical near East had discovered to domesticate animals, grow plants, and convey useful articles of pottery and metal long before the Greeks or Romans (Hause and Maltby, 2004, p. 1). Father of History Herodotus (484 BC-425 BC) became probably the basic early historian who knowingly narrated the East (Persians) and the West (Hellen) as opposing opponents, thereby providing the nucleus of all ancient history. Another historians, Xenephone (430 BC-354 BC), and Thucydides (460 BC-400 $\mathrm{BC})$, farther, were discovered it natural to hire strong polarities and concentrate on the discrepancy of the East, whilst accepting the necessity of resistance to external force by means of defining a Western being. Hence came into being the primary machine of the so-referred to as East-West dichotomy.

Therefore it is not wrong to put forward a second historical analogic approach focused the supply component of the tourism system model. After the dark age of Hellen mainland (1200 BC-800BC) society's revival was well under way. Hellens' prosperity endured into the early Archaic period (ca. 700-600 B.C.E.), which noticed the rise of the political unit referred to as poleis (city state) (Sacks and Brody, 2005). In comparison to the bronze age, there developed a massive wide variety of separate, small communities, which often, and in particular towards the south and east, took the shape of poleis, 'city states', which comprised a town and the farm land around it and which aspired to a high degree of independence and selfsufficiency. Athens and Sparta evolved in unusual ways, a good way to grow to be a lot large than most, and in the 5th century to come to be rivals for supremacy in Greece (Rhodes, 2007, p. 2). To moderns, Athens represents the model Greek poleis - free, cultivated, and inquiring - but to the ancients, and to many Athenians, an alternative existed (Hause and Maltby, 2004, p. 34).Greek Poleis's start to found colonies after 500 B.C. Founding a colony required careful preparation. The "mother" Polis (Metropolis) had to choose a site for the colony, obtain divine approval for it, plan out the new settlement, and choose its 
Oikistes (founder), always, of course, a man of high status. The Greek word for colony was Apoikia, literally a "home away [from our old home]." Otherwise, however, the colony was a new and completely independent polis, since those who joined a colony gave up their citizenship in the mother Polis (Pomeroy et al., 2004, p. 66).

Far away to the south, in a remote valley of the Peloponnese, lay Sparta. Sparta was an aristocratic garrison state. The first Spartans were probably a band of Doric invaders who established their polis on the ruins of an earlier society. They displaced an earlier ruling class that was probably Dorian as well, allowing these Perioikoito retain property and personal freedom within their own communities. The original pre-Dorian inhabitants became serfs or in Spartan terms, helots. (Hause and Maltby, 2004, p. 34).

Table 4: Target and source notions of supply and hellenism

\begin{tabular}{|l|l|}
\hline Target Notion & $\begin{array}{l}\text { Source Notion } \\
\text { (Analog) }\end{array}$ \\
\hline Advanced Economies (origin) & Greek Poleis \\
\hline $\begin{array}{l}\text { Emerging Economies } \\
\text { (destination: in particular } \\
\text { holiday villages of mass } \\
\text { tourism) }\end{array}$ & $\begin{array}{l}\text { Apoikia (Home } \\
\text { Away)Colonies }\end{array}$ \\
\hline Tourist & $\begin{array}{l}\text { Periokoi (specific to } \\
\text { city state of Sparta) }\end{array}$ \\
\hline Tourism Employees & $\begin{array}{l}\text { Helots (specific to } \\
\text { city state of Sparta) }\end{array}$ \\
\hline
\end{tabular}

A table of target and source notions of supply and Hellenism analogy can be seen in Table 4 .

Sparta, in the south of the Peloponnese, had not one king but two, probably a result of the amalgamation of neighboring communities; it retained these into the classical period and beyond, though many of their powers were transferred to an annually appointed board of five Ephors ('overseers'). By the eighth century it had conquered the whole of its region of Laconia, making some of the inhabitants Perioikoi ('dwellers-around', independent within their own communities but dependent on Sparta in foreign policy) and others helots (a word which probably means 'captives', a serf class working the land of its Spartan owners: they are the best-known but not the only instance of a serf class in early Greece).

The holiday villages of mass tourism is and obvious example for the Apoikia. Similar to colonies, holiday clubs were established. In the name of Mass Tourism Western Tourists travel to sun, sea and sand attractions they stay in big luxury holiday clubs where they spend their holiday like in their home away (Apoikia). As an example according to Turkish Culture and Tourism Ministry (2018) Turkey is a home to 116 holiday villages ( 82577 beds) with tourism investment certificate and operation license.

\section{CONCLUSION}

This study tries to state a criticism of contemporary tourism through evaluating it by historical facts. Nevertheless, the main constraint of this criticism is based on the western dominant tourism. Two critical analogic approaches were suggested for the interpretation of Western shaped tourism system assumptions. Moreover, there may be a lack of conception while dealing with mass tourism as it is generally perceived as sea, sun and sand tourism. There have been hardly the debates about why travelling for skiing in a mountain is not regarded as a mass tourism activity. Thus, the lacking parts of this assumption was tried to be found in the history. This might cause anachronism which is not generally regarded positively in historical thought as it evaluated the actual by the judgements of the past. However, it may reveal a brand new paradigm about the formation of contemporary tourism as putting the bricks one by one as a starting point. In order to gain a better understanding of tourism, more criticism and analogic approaches might be useful to put forward.

\section{REFERENCES}

Hall, M. (2008). Tourism planning, policies, processes and relationships, Second edition, Pearson: UK.

Hause, S. \& Maltby, W. (2004). Western Civilization: A History of European Society, Wadsworth Publishing: USA.

IMF (2017). World economic outlook of april 2017. www.imf.org/en/publications/weo [Access Date: 19.02.2018]

Kagan, D. (2007). An introduction to ancient Greek history, Open Yale Courses, http://www.acikders.org.tr/file.php/101/Lectures/P DF/Ders04.pdf [Access Date: 19.02.2018] 
Leiper, N. (1981). Towards a cohesive curriculum in tourism: the case for a distinct discipline. Annals of Tourism Research, 8(11), pp. 69-84.

Page, S. (2007). Tourism Management: Managing for Change Second Edition. Elsevier: Oxford.

Pew Research Center (2017). The changing global religious landscape.

http://www.pewresearch.org/fact-

tank/2017/04/05/christians-remain-worlds-largestreligious-group-but-they-are-declining-in-europe/

[Access Date: 12.02.2018].

Pomeroy, S. B., Burstein, S. M., Donlan, W., and Roberts, J. T. (2004). A Brief History of Ancient Greece Politics, Society, and Culture, Oxford University Press: New York.

Santayana, G. (1905). The Life of Reason, Prometheus Books: New York.

Turkish Culture and Tourism Ministry (2018). Statistics of tourism establishments with tourism investment certificate and operation license 2016, http://yigm.kulturturizm.gov.tr/TR,9860/turizmbelgeli-tesisler.html [Access Date: 22.02.2018].

UNSD (United Nations Statistics Division) (2014). Population by religion, sex and urban/rural residence.

http://data.un.org/Data.aspx?d=POP\&f=tableCode \%3A28 [Access Date: 27.02.2018].

UNWTO (United Nations World Tourism Organization) (2017). Tourism highlights 2017 edition. https://www.e unwto.org/doi/pdf/10.18111/9789284419029

[Access Date: 19.02.2018].

Urry, J. \& Larsen, J. (2011). The Tourist Gaze 3.0, Sage Publishing: London.

http://www.datagraver.com/case/world-populationdistribution-by-latitude-and-longitude-2015

[Access Date: 19.02.2018].

https://dictionary.cambridge.org/tr/s\%C3\%B6zl\%

C3\%BCk/ingilizce/heaven [Access Date:

26.02.2018].

https://unstats.un.org/unsd/demographic-

social/products/vitstats/seratab1.pdf [Access Date: 24.02.2018].

http://www.bbc.com/news/magazine-19922863

[Access Date: 06.03.2018]. 